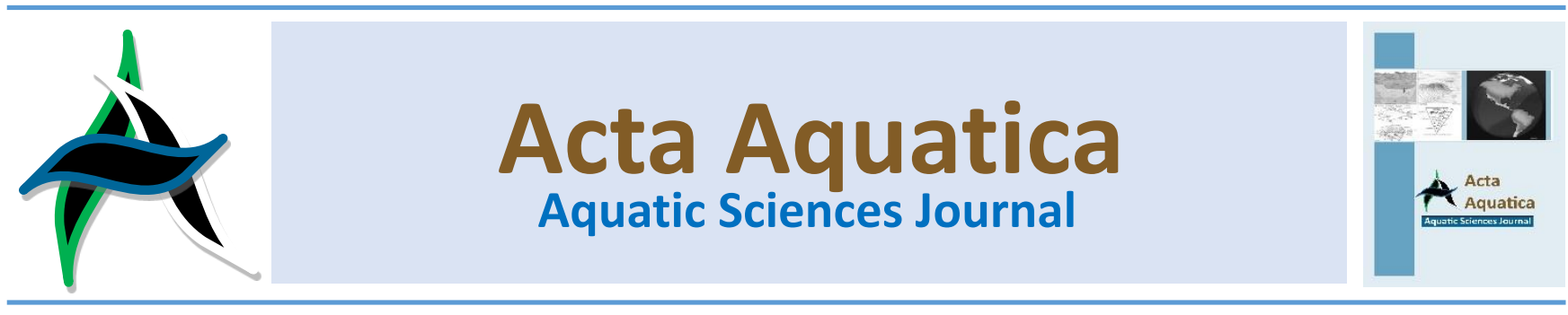

\title{
Daya terima dan kandungan mutu bakso ikan kambing-kambing (Abalistes stellaris) dengan penambahan asap cair dan simpan pada suhu dingin
}

\section{The acceptances and quality content of kambing-kambing (Abalistes stellaris) fish meatball with applying liquid smoke concentrations and storability in cold temperature}

\author{
Dwi Apriliani AGS ${ }^{*}$, dan Nurhayati ${ }^{\text {b }}$ \\ ${ }^{a}$ Program Studi Teknologi Hasil Perikanan, Fakultas Perikanan, Universitas Abulyatama \\ ${ }^{b}$ Program Studi Budidaya Perairan, Fakultas Perikanan, Universitas Abulyatama
}

\begin{abstract}
Abstrak
Pada umumnya masyarakat gemar dengan olahan bakso ikan. Namun, Kendala yang dihadapi adalah bakso tersebut mudah terdegradasi oleh bakteri pembusuk dan tidak tahan lama. Pengawet alami yang aman untuk produk perikanan salah satunya adalah asap cair dan penyimpanan suhu dingin. Tujuan penelitian bakso ikan kambing-kambing asap untuk mengetahui daya terima masyarakat (uji organoleptik), Escherichia coli, Angka Lempeng Total dan Salmonella, Dengan konsentrasi penambahan asap $1 \%, 3 \%$, dan $5 \%$ serta lama penyimpanan 0 , $10,20,30$ hari pada suhu dingin. Hasil penelitian menunjukkan bahwa Konsentrasi asap cair yang berbeda memberi pengaruh nyata $(P>0,05)$ terhadap daya terima (Uji Organoleptik) dan daya simpan pada suhu dingin bakso Ikan Kambing-kambing. Selanjutnya kandungan mutu meliputi E.coli dan ALT berpengaruh nyata $(p>0,05)$ terhadap konsentrasi asap cair dan lama simpan pada suhu dingin. Namun terhadap Salmonella tidak berpengaruh nyata $(p<0,05)$.
\end{abstract}

\begin{abstract}
Nowdays fish meatball process was delighted by people. However, the obstacles faced are degraded easily by bacteria decay and nondurable. Liquid smoke is one of the safe natural preservatives for fishery products. The purpose of this study was to find out the acceptance of people regarding Organoleptic test, Escherichia coli, Total Plate Count (ALT), and Salmonella 1\%, 3\%, and $5 \%$ then $0,10,20,30$ days were concentrations added of liquid smoke and during storage at cold temperatures respectively. The results showed that applying different liquid smoke concentrations and storability gave a significant effect $(P>0.05)$ on acceptance of people of kambing-kambing fish. The quality content of E.coli and ALT had significant effect ( $p>0.05$ ) respectively on liquid smoke concentrations and during storage at low temperature but had no significant effect on Salmonella.
\end{abstract}

Keywords: fish meatball; liquid smoke; quality

\footnotetext{
* Korespondensi: Program Studi Teknologi Hasil Perikanan, Fakultas Perikanan, Universitas Abulyatama. Jl. Blang Bintang Lama Km 8,5, Lampoh Keudee, Aceh Besar, 23272Provinsi Aceh, Indonesia. Tel: +62-651-21255.

e-mail:dwiags02@gmail.com
}

\section{Pendahuluan}

Ikan kambing-kambing segar yang di tangkap pada perairan Aceh mengalami peningkatan pada tahun 2012 sekitar \pm 5000 ton/tahun, dirata-ratakan $\pm 426.147 \mathrm{~kg} / \mathrm{bulan}$ (UPTD PP Lampulo, 2012). Masyarakat Aceh cenderung tidak menyukai ikan tersebut, dikarenakan kulitnya yang relatif keras dan sukar untuk disiangi.

Ikan kambing-kambing mempunyai tekstur daging putih, padat dan kompak sehingga cocok untuk dijadikan sebagai bahan diversifikasi produk hasil perikanan seperti bakso, nugget, kaki naga, sosis, ekado dan lain-lain.

Salah satu produk yang populer di kalangan masyarakat adalah bakso. Bahan baku bakso dapat berasal dari daging ikan, sapi, udang dan lain-lain. Jenis ikan yang paling sering digunakan 
untuk pembuatan bakso adalah ikan tenggiri. Namun, Ikan tersebut harganya relatif mahal, sehingga perlu dicari alternatif lain untuk menggantikan bahan baku tersebut. Ikan kambingkambing menjadi salah satu alternatif bahan baku yang memenuhi syarat untuk pembuatan bakso. Salah satu kendala dalam bakso ikan adalah mudah terdegradasi oleh bakteri pembusuk selama proses penyimpanan. Alternatif dalam menekan pertumbuhan bakteri pembusuk dengan menggunakan asap cair (liquid smoke) dan disimpan pada suhu dingin.

Asap cair merupakan bahan kimia hasil destilasi asap hasil pembakaran. Kelebihan asap cair yaitu dapat menghasilkan produk yang seragam, rasa yang ditimbulkan dapat terkontrol, dapat memberikan cita rasa dan aroma yang konsisten, menghemat kayu, mengurangi polusi dan dapat mencegah deposit senyawa tar (Swastawati, 2007). Asap cair tidak hanya berperan dalam membentuk karakteristik sensoris, tetapi juga dalam hal jaminan keamanan pangan (Martinez, et al, 2007).

Berdasarkan uraian tersebut, maka akan dilakukan penelitian lebih lanjut mengenai ikan kambing-kambing yang diolah menjadi produk bakso dengan penambahan asap cair dan disimpan pada suhu dingin. Penambahan asap cair ini diharapkan mampu mempertahankan mutu bakso ikan, rasa yang enak dan dapat diterima masyarakat.

Penelitian ini bertujuan untuk mengetahui daya terima masyarakat dari uji organoleptik, Angka Lempeng Total, Salmonella, dan Escherichia coli bakso ikan kambing-kambing dengan konsentrasi penambahan asap 1\%, 3\%, dan 5\% serta lama penyimpanan $0,10,20,30$ hari pada suhu dingin

\section{Bahan dan metode}

\subsection{Waktu dan tempat}

Penelitian ini dilaksanakan mulai bulan Maret-Agustus 2017 di Banda Aceh. Pengolahan Bakso Ikan dilakukan di Laboratorium Teknologi Hasil Perikanan (THP), Fakultas Perikanan Universitas Abulyatama. Uji Baku mutu dilakukan di Laboratorium Balai Riset dan Standarisasi Industri (BARISTAND) Banda Aceh.

\subsection{Bahan dan alat}

Bahan- bahan yang digunakan dalam penelitian ini adalah daging ikan kambing-kambing (60\%) dan tepung tapioka, asap cair, bawang merah, bawang putih, lada, gula, garam, air es (40\%). Peralatan yang digunakan adalah panci, food processor, blender, talenan, pisau, dan peniris.

\subsection{Metode penelitian}

Metode yang digunakan dalam penelitian ini adalah eksperimental laboratoris, yaitu metode dimana untuk memperoleh data dilakukan percobaan dan pengujian laboratorium. Untuk memperoleh data dilakukan pengamatan dan pencatatan terhadap aspek organoleptik, Angka Lempeng Total, Salmonella, dan Escherichia coli.

Tujuan penelitian eksperimental adalah untuk menyelidiki ada tidaknya hubungan dari pemakaian asap cair serta berapa besar hubungan sebab akibat dari lama penyimpanan (Nazir, 2005). Sedangkan menurut Gomes (2005)), metode eksperimen laboratoris menunjukkan adanya hubungan sebab akibat yaitu membandingkan satu atau lebih kelompok eksperimen yaitu asap cair yang diberi perlakuan.

\section{Hasil dan pembahasan}

3.1. Uji organoleptik bakso ikan kambing-kambing (Abalistes stellaris) asap

Penampakan merupakan parameter organoleptik yang penting, karena merupakan sifat sensoris yang pertama kali dilihat oleh konsumen. Bila kesan penampakan produk baik atau disukai, maka konsumen baru akan melihat sifat sensoris yang lainnya (aroma, rasa, tekstur dan seterusnya).



Gambar 1. Hasil uji organolpetik bakso ikan dengan penambahan asap cair $1 \%$.

Berdasarkan Gambar 1 hasil uji organoleptik ikan kambing-kambing dengan penambahan asap cair $1 \%$ diatas menunjukkan bahwa untuk konsentrasi asap cair $1 \%$ tidak banyak mengalami penurunan kesukaan selama masa penyimpanan dingin. Pada hari ke 0, 10, 20 dan 30 nilai rata-rata organoleptik bakso ikan kambing-kambing asap dengan konsentrasi asap cair $1 \%$ sebesar 7.62, 7.52, 7.53 dan 7.41 . Berdasarkan SNI 01-7266.1-2006 persyaratan organoleptik bakso ikan minimal 7.0 dari angka score sheet 1-9. Dengan karakteristik bentuk bulat beraturan, bau tidak amis spesifik bakso ikan, rasa ikan dominan, tekstur padat, kompak dan kenyal.

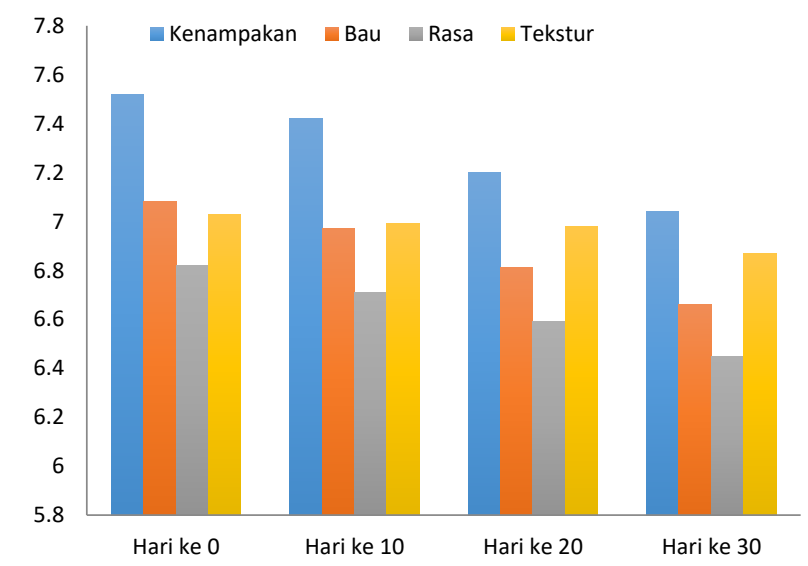

Gambar 2. Hasil Uji Kesukaan Bakso Ikan dengan penambahan asap cair 3\%.

Berdasarkan Gambar 2 hasil uji organoleptik ikan kambing-kambing dengan penambahan asap cair $3 \%$ selama masa penyimpanan dingin pada hari ke $0,10,20$ dan 30 sebesar 7.11, 7.02, 6.90 dan 6.76 . 


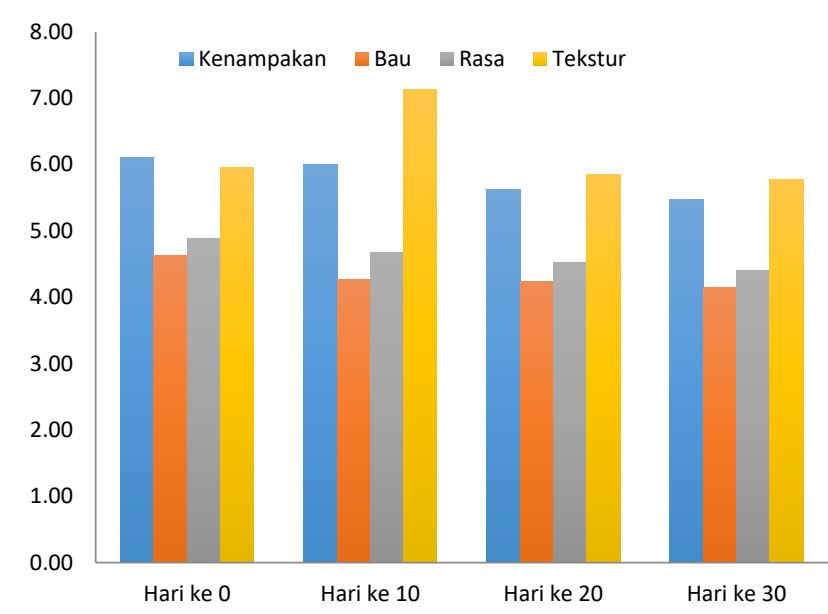

Gambar 3. Hasil uji kesukaan bakso ikan dengan penambahan asap cair $5 \%$.

Berdasarkan Gambar 3 hasil uji organoleptik ikan kambing-kambing dengan penambahan asap cair $5 \%$ selama masa penyimpanan dingin pada hari ke $0,10,20$ dan 30 sebesar $5.39,5.52,5.06$ dan 4.95 .

\subsection{Angka lempeng total}

Berdasarkan hasil penelitian selama 30 hari pada bakso ikan kambing-kambing dengan penambahan asap cair 1\%, 3\% dan $5 \%$ dengan penyimpanan dingin hari ke $0,10,20$ dan 30 hari maka didapat hasil Angka Lempeng Total dapat dilihat pada Gambar 4.

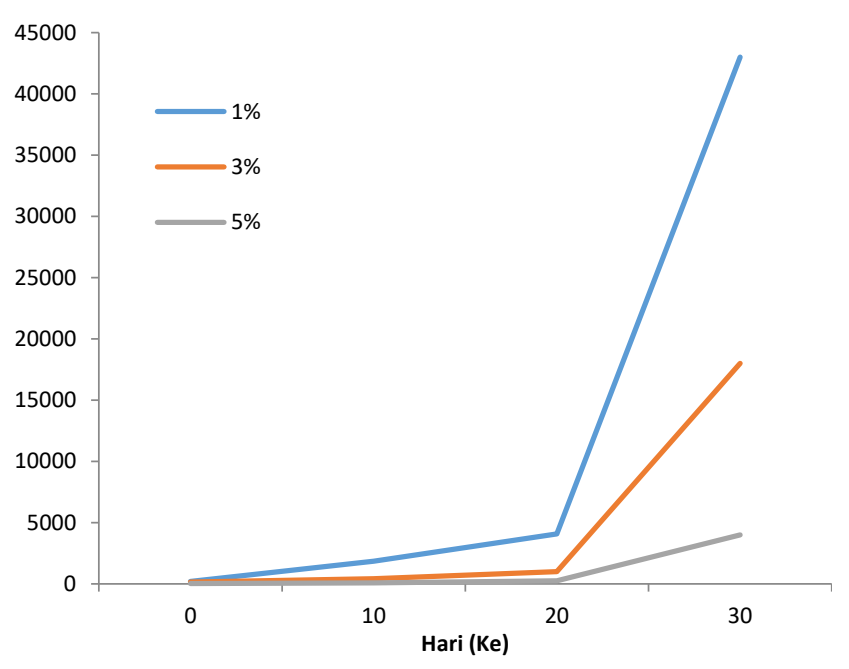

Gambar 4. Hasil angka lempeng total (ALT) bakso ikan kambing-kambing asap.

Berdasarkan Gambar 4. Hasil pengujian Angka Lempeng Total (ALT) bakso ikan kambing-kambing (Abalistes stellaris) asap pada penyimpanan suhu dingin dengan konsentrasi asap cair $1 \%$, $3 \%$ dan $5 \%$ dengan lama penyimpanan 0 hari, 10 hari, 20 hari dan 30 hari adalah sebesar $2,0 \times 10^{2} ; 1,85 \times 10^{3} ; 4,08 \times 10^{3}$ dan 4,3 $x$ $10^{4}$. Penambahan asap cair $3 \%$ dengan lama penyimpanan 0 hari, 10 hari, 20 hari dan 30 sebesar $1,5 \times 10^{2} ; 4,3 \times$ $10^{2} ; 10 \times 10^{3}$ dan $1,8 \times 10^{4}$. Penambahan asap cair $5 \%$ dengan lama penyimpanan 0 hari, 10 hari, 20 hari dan 30 sebesar $28 ; 7,5 \times 10^{1} ; 2,6 \mathrm{x}$ $10^{2}$ dan $4,0 \times 10^{3}$. Keseluruhan nilai tersebut lebih rendah dari persyaratan mutu menurut Persyaratan Mutu SNI 01-7266.1-2006 dengan jumlah ALT maksimum adalah $5 \times 10^{5}$ koloni/gram. Rendahnya nilai ALT ini menggambarkan bahwa bakso ikan kambing- kambing tersebut layak dikonsumsi. Hasil ini sesuai dengan pernyataan Muratore et al. (2007) bahwa bakso ikan yang di rendam asap cair dan tidak di pasteurisasi memiliki nilai ALT yang lebih kecil dibanding dengan sampel bakso ikan yang tidak direndam dengan asap cair dan tidak dipasteurisasi. Hal tersebut menunjukkan bahwa asap cair memiliki beberapa keunggulan salah satu nya memliki aktivitas antibakteri.

\subsection{Salmonella}

Hasil Uji Salmonella terhadap Bakso Ikan Kambingkambing dengan penambahan asap cair $1 \%$, 3\% dan $5 \%$ dengan penyimpanan suhu dingin $0,10,20$ dan 30 hari dapat dilihat pada Tabel 1.

Tabel 1.

Paramater jumlah mikroba Salmonella

\begin{tabular}{cccccc}
\hline Parameter & Hari & $\begin{array}{c}\text { Asap } \\
\text { cair 1\% }\end{array}$ & $\begin{array}{c}\text { Asap } \\
\text { cair 3\% }\end{array}$ & $\begin{array}{c}\text { Asap } \\
\text { cair 5\% }\end{array}$ & $\begin{array}{c}\text { Persyaratan } \\
\text { SNI. 7388: } \\
2009\end{array}$ \\
\hline Salmonella & 0 & Negatif & Negatif & Negatif & Negatif/25g \\
Salmonella & 10 & Negatif & Negatif & Negatif & Negatif/25g \\
Salmonella & 20 & Negatif & Negatif & Negatif & Negatif/25g \\
Salmonella & 30 & Negatif & Negatif & Negatif & Negatif/25g \\
\hline
\end{tabular}

Berdasarkan Tabel 1 hasil uji Salmonella terhadap bakso ikan asap adalah negatif. Hal ini menunjukkan bahwa dari awal produksi hingga penyimpan tidak terjadi kontaminasi. Bakso ikan asap ini sesuai dengan Standar Nasional Indonesia (SNI) tahun 2009 tentang jumlah koloni yang diperkenankan adalah negatif/25g. Pernyataan tersebut sesuai dengan yang dikemukakan oleh Yuliana (2011) bahwa asap cair dapat menghambat pertumbuhan bakteri Salmonella dan jamur Rhizopus. Penyimpanan pada suhu dingin sangat baik dilakukan karena bakteri Salmonella tidak dapat hidup pada suhu dibawah 15 derajat celcius dan diatas 45 derajat celcius. Suhu optimum pertumbuhan Salmonella adalah 37.5 derajat celcius.

\subsection{Escherichia coli (E. coli)}

Berdasarkan penelitian yang telah dilakukan terhadap pengaruh pemberian asap cair pada bakso ikan kambingkambing (Abalites stellaris), maka ditemukan adanya bakteri Escherichia colli (Tabel 2).

Hasil penelitian menunjukkan bahwa hari 0, 10, 20 dan 30 , dengan konsentrasi asap cair 1\%, 3\% dan 5\%, mendapatkan hasil APM (Angka Paling Mungkin) <3/gr. Menurut Harvinosa (2011), asap cair memiliki kemampuan untuk mengawetkan bahan makanan karena adanya senyawa asam, fenolat dan karbonil. Sehingga penggunaan asap cair mampu menghambat pertumbuhan mikroba dan mampu mengurangi jumlah mikroba yang terdapat pada ikan. Menurut Putra (2010), kandungan senyawa asam pada asap cair yang sangat efektif dalam menghambat dan mematikan mikroba dengan cara senyawa asam ini menembus dinding sel mikroorganisme yang menyebabkan sel mikroorganisme menjadi lisis kemudian mati, dengan menurunnya jumlah bakteri maka dapat meningkatkan
Tabel 2.

Hasil pengujian Escherichia coli

\begin{tabular}{|c|c|c|c|c|c|c|c|}
\hline Hari & Parameter & Satuan & $\begin{array}{c}\text { Metode } \\
\text { uji }\end{array}$ & $\begin{array}{c}\text { Persyaratan } \\
\text { mutu SNI. } \\
\text { 7388: } 2009\end{array}$ & $\begin{array}{c}\text { Asap cair } \\
1 \% \\
\end{array}$ & $\begin{array}{c}\text { Hasil } \\
\text { Asap } \\
\text { cair 3\% } \\
\end{array}$ & $\begin{array}{c}\text { Asap } \\
\text { cair 5\% }\end{array}$ \\
\hline 0 & E. coli & APM/gr & APM & $<3 / g r$ & $<3$ & $<3$ & $<3$ \\
\hline 10 & E.coli & APM/gr & APM & $<3 / g r$ & $<3$ & $<3$ & $<3$ \\
\hline 20 & E.coli & APM/gr & APM & $<3 / g r$ & $<3$ & $<3$ & $<3$ \\
\hline 30 & E.coli & APM/gr & APM & $<3 / g r$ & $<3$ & $<3$ & $<3$ \\
\hline
\end{tabular}


umur simpan produk pangan. Berdasarkan Persyaratan Mutu Standar Nasional Indonesia (SNI). 7388: 2009 tentang persyaratan mutu bakso ikan bahwa Escherichia coli total maksimal <3APM/g.

\section{Kesimpulan}

Uji Organoleptik Bakso Ikan Kambing-Kambing selama penyimpanan $0,10,20$ dan 30 dengan penambahan asap cair $1 \%$ lebih tinggi dan lebih disukai panelis dibandingkan penambahan asap cair 3\% dan 5\%. Hasil Uji Angka Lempeng Total , E.coli , dan Salmonella Bakso Ikan Kambing-kambing dengan penambahan asap cair $1 \%$, 3\% dan $5 \%$ selama penyimpanan $0,10,20$ dan 30 hari masih dibawah ambang batas SNI, sehingga dapat direkomendasikan dapat dikonsumsi.

\section{Bibliografi}

Gomez, K.A., Gomez, A.A., 2007. Prosedur Statistik untuk Penelitian Edisi Kedua. Universitas Indonesia. Jakarta. $698 \mathrm{hlm}$. (Diterjemahkan oleh Endang Sjamsuddin dan Justika S. Baharsjah).

Harvinosa, R.L., 2012. Pengaruh Perbedaan Konsentrasi Asap Cair dari Beberapa Jenis Limbah Pertanian yang Berbeda Terhadap Mutu Ikan Nila Asap. Program Studi Teknologi Pangan Fakultas Teknik Universitas Pasundan. Bandung.

Martinez, O., Salmeron, J., Guillen, M.D., Casas, S., 2007. Textural and Physicochemical Changes in Salmon (Salmo Salar) Treated With Commercial Liquid Smoke Flavourings. Food Chemistry. Spain.

Muratore, G. and Licciardello, F., 2005. Effect of vacuum and modied atmosphere packaging on the shelf-life of liquidsmoked sword sh (Xiphiasgladius) slices. Journal of Food Science 70: 359-363.

Nazir, M., 2005. Metode Penelitian. Ghalia Indonesia. Bogor. 554 $\mathrm{hlm}$.

Putra, D., 2010. Asap Cair Pengawet Makanan. Asap-cairpengawet-makanan. wordpress.com. Diakses 04 Oktober 2016.

UPTD Pelabuhan Perikanan Lampulo, 2012. Data Ikan Kambingkambing. Banda Aceh.

Standar Nasional Indonesia, 2006. Bakso Ikan Beku SNI 017266.1-2006. Badan Standardisasi Nasional. Jakarta. 16 hlm.

Standar Nasional Indonesia, Batas Maksimum Cemaran Mikroba dalam Pangan. SNI. 7388: 2009. Badan Standardisasi Nasional. Jakarta. $37 \mathrm{hlm}$.

Swastawati, F., 2007. Pengasapan Ikan Menggunakan Liquid Smoke. Badan Penerbit Universitas Diponegoro. Semarang. $75 \mathrm{hlm}$.

Yuliana, N., Dizon, E.I., 2011. Phenotypic identification of lactic acid bacteria isolated from Tempoyak (fermented durian) made in the Philippines. International Journal of Biology, Vol. 3 (2): 145-152. 